\title{
GEOTHERMAL DEVELOPMENT AND THE SALTON SEA
}

by

\section{MARTIN GOLDSMITH}

EQL MEMORANDUM NO $\ldots 17$

February 1976 
Martin Goldsmith

EQL MEMORANDUM NO. 17

FEBRUARY 1976

ENVIRONMENTAL QUALITY LABORATORY

California Institute of Technology

Pasadena, California 91125

Sponsored by NSF Grant No. AER75-08793 
PREFACE

One of the limiting factors on energy development in the arid American West is the availability of water. Even geothermal development must take into account the hydrologic cycle of the surrounding area. In the Imperial Valley, the bloodstream of the economic body is water, and owing to the nature of the region and its water source, the mineralized Colorado River, the disposal of waste water is of major importance. The Salton Sea is presently the sump for agricultural drainage in that area. Quite incidently, the sea has become popular for recreational use.

It is universally recognized that geothermal development in the Valley will involve the flow to the surface of large quantities of highly mineralized water. After extraction of heat, the water must be safely disposed of. Moreover, many geothermal power generation methods would require cooling water supplies, and other methods may require water for reservoir injection. The point is that geothermal development may well impact the hydrologic cycle. Conversely the requirements of the local hydrologic cycle may well impact the nature of geothermal development. The purpose of this study is to examine the relationship of the Salton Sea, a key element of the Imperial Valley water system, to potential geothermal development.

The author would like to acknowledge the contributions of his late colleague, Alexander Martin Rodriguez, to this work. He had formulated a method of computing the behavior of the Salton Sea under a variety of future conditions, using a pocket-sized programmable computer. His work was left unfinished at his death, and was completed by Ms. Betsy Krieg. 
TABLE OF CONTENTS

Page

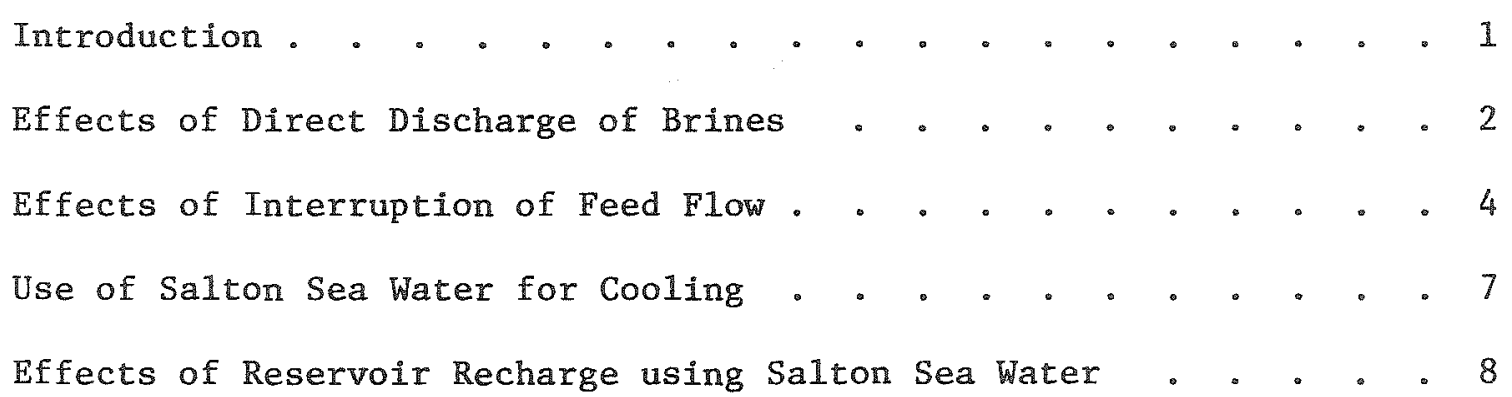

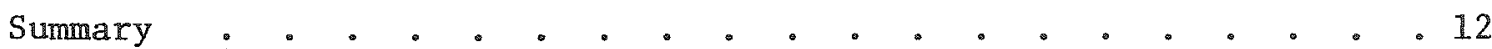

References • . • • . . . . . . . . . . . . . 15 


\section{Introduction}

The Salton Sea is a closed sump. It is fed in small part by local precipitation and runoff, but the greatest source is agricultural drainage. This drainage is vital for the maintenance of irrigated agriculture in the Imperial Valley. Without the Sea as a great evaporation pond, the relatively impervious sub-soil would cause the productive topsoil to become salt-laden and sterile. If the level of the sea should rise too far, the surrounding low-1ying farm area will not drain and will be useless. Seen from another viewpoint the Sea has become a unique recreational resource in Southern California. The Sea provides for fishing and other water recreation, hunting, and contains a wildfowl refuge. The continued viability of the Salton Sea for these purposes depends on the maintenance of adequate water quality. While the drainage is also vital for the life of the Sea, it contains elements of its destruction. Without the drainage the Sea would dry up; with the drainage comes the dissolved minerals that are gradually but steadily increasing the salinity of the Sea. The salinity already exceeds that of the oceans, and it is predicted that within a few years the salinity will be so high as to begin the destruction of the fishery. Subsequently, all watex sport and the wildfowl will be adversely affected.

All this has been exhaustively treated in several major studies (References 1-4), and the nature of the problems and proposed solutions will not be covered here. A brief, non-technical review of the history of the Salton Sea is given in Reference 5. It has long been recognized that geothermal development in the Imperial valley could have effects on the Salton Sea, ranging from highly destructive to neutral to highly beneficial. For example, during some geothermal well tests made in 1962, a substantial quantity of hot brine flowed into the Salton Sea. This was of sufficient concern to the Regional Water Quality Control Board (RWQCB) that resolutions were adopted prohibiting the practice (Ref. 6). On the other hand, it has been pointed out (Ref. 7) that 
by drawing water from the Salton sea for purposes of reinjection, the level and salinity of the Sea might be controlled. One fairly detailed examination of this concept is given in Reference 8 . It is the purpose of this review to consider in a quantitative fashion what some potential effects of geothermal development might be on the Salton Sea.

\section{Effects of Direct Discharge of Brines}

After an exploratory geothermal well is drilled, a flow test is essential to establish its productivity and worth. Disposal of the produced brine poses a difficult problem in many cases. If there is a nearby well suitable for reinjection, the wells can be connected and brine disposal can be accomplished in that fashion. Another method is to employ a solar pond, where the water can be evaporated away. This method is not without environmental hazards, however, The sides and bottom must be designed to be impervious, either by appropriate choice of earthen lining material, plastic film liner, or other means. However, in the event of liner failure, the accumulated water and salts can escape into the surrounding area, contaminating the soil or ground water. Even without a liner failure, the pond can be hazardous. For example, a flooding situation, even many years after the pond had evaporated to dryness, might permit the accumulated salt to escape the confines of the pond. If the pond is fully or partially above grade, a seismic event could rupture the walls, permitting escape of the ponded fluids.

In any event, ponds may not represent an economic means of disposal. An Imperial Valley geothermal well of commercial value typically might flow one-half million pounds/hour of brine, or close to five acre-feet per day. For a truly meaningful test, weeks or even months of flow might be required. With an annual evaporation rate of about five feet, it is obvious that hundreds of acres would be required for useful evaporation ponds. 
Clearly, therefore, considering the expense of drilling an injection well (about the same as for a production well) or the cost and difficulty of obtaining land for ponds, there will be considerable pressure to pass the waste into the Salton Sea. How severe a hazard would that be? At the Salton Sea KGRA, * the brines vary from 20 to 30 percent solids content. Thus the added mineral load to the Salton Sea from the flow of one well wight typically be $100,0001 \mathrm{bs} / \mathrm{hr}$. In a one-month flow test, the Sea would receive over 35,000 cons of salts. The total annual salt inflow to the Salton Sea from its normal feedwater is 4.4 million tons (Ref. 4). While one such test per year would contribute less than one percent additional salt load to the Sea, extended testing, or testing of several wells, would clearly increase the salt content of the Salton Sea by a noticeable amount.

In other KGRA's the salinity of the brines is substantially less (by an order of magnitude). Such wells, if tested for a oneyear period, would add approximately one percent to the salt flow to the Sea. While a single isolated instance of a well's flow being disposed of in the Sea does not lead to instant environmental catastrophe, it is also clearly the case that widespread, continuous disposal could greatly accelerate the demise of the recreational resource. At the present, with the salinity of the Salton Sea approximating $38,000 \mathrm{mg} / 1$ (the critical level for survival of fish larvae is about 40,000 mg/1) and increasing at the rate of about $500 \mathrm{mg} / 1 / \mathrm{yr}$ (Ref. 4), it is clear that the critical level is uncomfortably close. While hopes for the eventual construction of a salinity control system are alive, the rationale for the RWQCB restrictions on dumping into the sea or its tributaries is well founded. It is worthwhile to note that the overall mineral loading of the Salton Sea is not the only problem that might be brought about by geothermal discharge. In most cases, in addition to the major mineral constituents of geothermal brine, the flow contains trace elements (substances of low concentration) that may be

*Known Geothermal Resource Area, a legal term. 
harmful to living organisms. Therefore no general limits can be laid down, but this class of problem provides further support for the RWQCB position (Ref.9).

There is another aspect to brine disposal in the Salton Sea beyond water quality. Even in the event that the Sea is lost as a recreational resource and written off, limits on disposal exist. If the Sea receives increased input, from whatever source, its level will rise until the evaporation from the increased surface area just balances the added inflow. How severe a problem might this be? Consider a 100 MW electric plant operating on high temperature brine (direct flash stean cycle) and disposing of the waste brine to the Salton Sea. If the wells discharge a mixture of 80 percent water and 20 percent steam, and the turbine steam rate is $20 \mathrm{lbs} / \mathrm{kw}-\mathrm{hr}$, such a plant would discharge 74 acre-feet/day, or nearly 27,000 acre-feet/year (Ref. 10). Thus the continuing addition of the 27,000 acre-feet/year would require a sea surface area increase of 4,655 acres. According to the level-area-capacity relations of Reference 4 derived from U.S. Geological Survey data, such an increase would correspond to a level increase from -232 feet to -230.6 feet (approximately). If only one $100 \mathrm{MW}$ plant can result in such an increase in elevation, it is clear that a major power development, say 1,000 MW, would have a most significant effect. Drainage patterns in the lower parts of the Imperial Valley would be seriously affected. Water quality considerations aside, the Salton Sea cannot be used as a repository for large amounts of geothermal brine.

\section{Effects of Interruption of Inflow}

It has been proposed in several places that closed-cycle geothermal power generation schemes use the irrigation waste water in the Imperial Valley as make-up water in evaporative cooling towers. In some parts of California the use of waste water for power plants may be very advantageous to agriculture (see Ref. 11). In the Imperial 
Valley, however, the Salton Sea has accomplished the purpose of waste water disposa1. If the waste waters are diverted to cool power plants, the feed to the Sea will be reduced. In this case the level of the Sea would fall to a new equilibrium value, and its salinity would be increased. (The existing salt load would be diluted in less water even though the saline cooling tower blow-down would not be returned to the Sea.)

In Reference $10 \mathrm{it}$ is estimated that approximately 60 acre-feet/ year of cooling water per MW electrical capacity is needed for Cerro Prieto-like geothermal power plants (flash steam system). Thus a 100 MW plant requires 6,000 acre-feet/year. Such a diversion would, if continued over several years, lower the sea level by about three inches and increase the salinity by approximately $350 \mathrm{mg} / 1$. While such a diversion is probably not significant, the diversion corresponding to 1,000 MW base load electric production, about 60,000 acre-feet/year, would finally result in a level drop of 2-1/2 feet and a salinity increase of more than $3,500 \mathrm{mg} / 1$ over the value that would otherwise be found at that time. The behavior of the sea with time under that circumstance is shown in Figure 1, calculated according to the method of Reference 3. The situation where a closed-cycle binary power plant is used with a lower temperature reservoir accentuates this behavior. In Reference 12 it is calculated that such a power plant will require up to 3.7 acre-feet/day for a $10 \mathrm{MW}$ capacity. Thus $1,000 \mathrm{MW}$ of electrical capacity would require 135,000 acre-feet/year.

The conclusion to be drawn seems straightforward. If no control plan is implemented to correct the salinity problem of the Salton Sea, diversion of irrigation drainage for cooling simply adds to a deteriorating salinity situation. The amount that might be diverted in the next five years will have a negligible influence. After that time, the predicted course of events will have probably marked the end of the fishery in most of the Sea, although in the area near the mouths of the New and Alamo Rivers, fish and wildlife could continue to exist. 


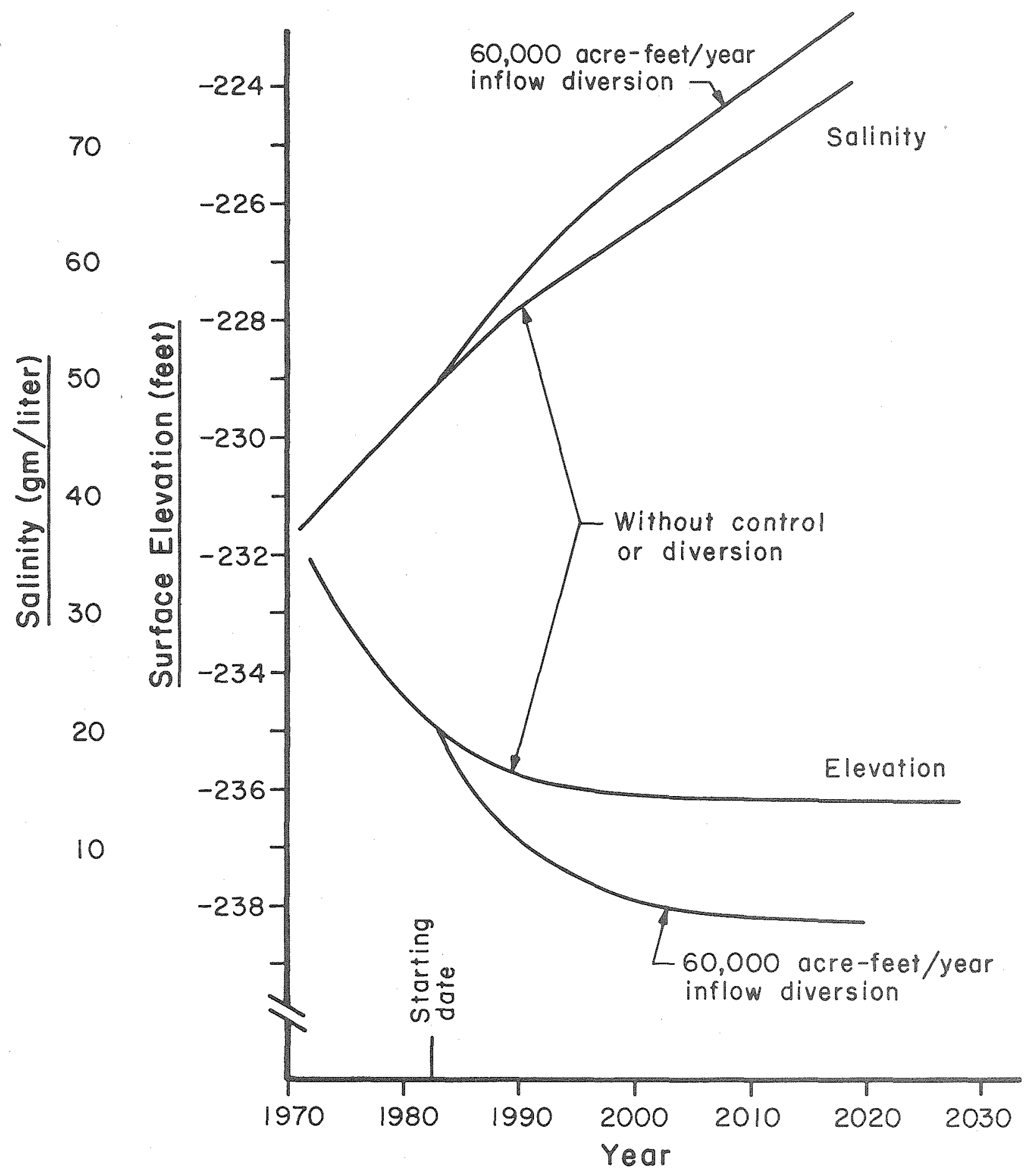

Figure 1 Behavior of Salton Sea With and Without Diversion of Inflow 160,000 acre-ft/yr for cooling $1000 \mathrm{mw}$ geothermal power plants no return of blow-down to sea) 
Major diversions for cooling will simply elevate an already intolerable salinity level.

The effects of diversion of the Sea's feed water are less clear if a salinity control project is built. The design and operation of a specific control scheme must be considered if even an estimate is to be given. In the most recent study. Reference 4, it was stated that the effects of man-made events (such as inflow diversion) were not calculated. However, as a sample, it was pointed out that for a 50 square mile diked impoundment (a recommended method of salinity control) a decrease in inflow of 300,000 acre-feet/year (approximately) beginning in 20 years would have serious effects on water level, as a drop to -246 feet might be expected. Therefore, while a control project may be able to accommodate some level of diversion, it is clear that a definitive conclusion regarding acceptable diversion would require careful study.

\section{Use of Salton Sea Water for Cooling}

Another possibility for the cooling of geothermal power plants, particularly for those located close to the Salton Sea, is once-through systems as employed in coastal power plants. New coastal plants must now meet strict regulations concerning the rise of temperature of waters close to the power plant outfalls. The problem has not yet arisen of an increase in general ocean temperature from themal discharge. The problem is different at the Salton Sea, however. Not only would regulations have to be met in the vicinity of the plant, * but attention must be given to the effect on the whole of the Sea. The reason is that while the flow through a major power plant is but a tiny part of the coastal ocean currents, the annual flow through a power plant complex might be a major fraction of the total content of the Salton Sea. Thus the heat from a power plant will be a significant factor in the heat balance of the Sea.

*In the governing State policy instrument, "Policy Regarding the Control of Temperature in the Coastal and Interstate Waters and Enclosed Bays and Estuaries of California," of the State Water Resources Control Board, adopted October 13, 1971, it is not clear in which category the Salton Sea would fall. Therefore, specific regulatory requirements are not apparent to the author. 
Typically, a $1000 \mathrm{MW}$ nuclear power plant might require a throughput of one million acre-feet of water each year. The total volume of the Salton Sea is only about six million acre-feet. Because geothermal power plants are less efficient than nuclear power plants, their cooling requirements are greater. Reservoir conditions and plant design will determine actual efficiency. In Reference 10, as an example, it was estimated that a geothermal plant in the Imperial Valley would require at least twice the cooling flow for a nuclear plant, because the heat rejection would be twice as great. Therefore, 1,000 MW of geothermal capacity would reject $4,000 \mathrm{NW}$ of heat. The effect on the Salton Sea of such a heat dissipation is calculated in Reference 3. There it is shown that if the heat can be evenly dispersed in the Sea the Sea temperature will rise by $1.3^{\circ} \mathrm{F}$ in calm conditions, with negligible increase in evaporation rate. The air is seldom calm, however. In a 40 mile/hour wind, the Sea temperature would only rise $0.5^{\circ} \mathrm{F}$, and evaporation would increase by 0.1 feet/year. (Thus, by cooling pond, cooling tower, or use of the Sea, power plant cooling is apt to rely on evaporation of water.) clearly these are upper limits on temperature rise and evaporation, and both seem within a reasonable range. These simple calculations do not answer several important questions, however. For example, how would one design a cooling intake and outfall system to avoid deleterious local effects and obtain the well mixed condition? Another question is what the maximum cooling capacity of the Sea might be. Both problems would be profoundly influenced by a salinity control project using the system of diked impoundments.

\section{Effects of Reservoir Recharge using Salton Sea Water}

Al1 of the previously discussed relationships of geothermal development to the Salton Sea have had consequences ranging from negligible to catastrophic. Another possibility remains, with beneficial results. In both References 3 and 4, the possibility of controlling the salinity of the Salton Sea by pumping out a certain amount 
of water each year was quantitatively considered. By removing salt in this manner and allowing the sea to seek a new equilibrium level below that which results from the balance of inflow and evaporation, it was shown that the increase in salinity could be arrested and a satisfactory level of salinity maintained. The mode of disposition of the pumped water is unimportant to the hydrologic balance of the Sea. Among the disposal schemes that have been considered are piping the water to the Gulf of California or the Laguna Salada in Mexico, pumping it to a dry lake, which would then serve as an evaporation pond, or injecting the water for pressure maintenance in a geothermal field.

Methods for salinity control which involve both pumping and a diked impoundment within the sea were studied in Reference 4. In those cases, pumping was to continue only during the initial period of project operation for from eight to fourteen years. Clearly a long-term geothermal program is incompatible with those methods. In Reference 3, however, pumping was treated as a permanent means of control. Here the geothermal development may provide a better match.

Simply put, to stabilize the salinity of the Sea at some value, say $35,000 \mathrm{mg} / 1$, an amount of salt equal to that being added each year by drainage must be removed from the Sea. Estimates of this quantity have varied, but the most recent value, reported in Reference 4, is 4.44 million tons/year. This amount of salts would be contained in 97,000 acre-feet of water of $35,000 \mathrm{mg} / 1$ total dissolved solids content. While removing this quantity of water will stabilize the Sea, the time required to adjust the projected level of salinity to the equilibrium value would take many years. This was illustrated in Reference 3 for various conditions.

How much geothermal development provides for the disposition of such a quantity of water? Several mechanisms are possible. The one that has been most widely considered is to use Salton Sea water as injection fluid in the geothermal reservoir. As water is produced 
from geothermal wells, the reservoir is depleted. (Natural recharge is expected to be too slow to prevent depletion.) A possible side effect of depletion is subsidence of the land surface. To avoid this, reinjection of the cooled geothermal fluids has been proposed, and in fact has been the preferred method of brine disposal in the Imperial Valley. However, in some modes of utilization of the geothermal resource, some of the produced brines are not available for reinjection. For example, if a flash steam process is used for the production of electricity, it is likely that the condensed steam will be used for make-up in evaporative cooling towers. As much as 20 percent of the water will be consumed in this way. If geothermal brine is used for feedstock in a desalting plant, even larger percentages of brine may be unavailable for reinjection. To make up the difference, Salton sea water might be used for supplementary injection fluid. A 100 MW geothermal power plant, using 20 pounds of steam per $k w-h r$, will remove two million $\mathrm{lbs} / \mathrm{hr}$ of steam from the well flow, or over 6,000 acre-feet of water in a year of operation. Thus the operation of twenty such plants, for a total of 2,000 MW electrical generating capacity, would provide a "sink" for an amount of Salton Sea water necessary to stabilize its salinity at a value safe for the fishery. Realistically, however, this is not an adequate solution to the salinity problem. Even if the entire 2,000 MW could be on-1ine in 1982, it would require until about $2020 \mathrm{~A} . \mathrm{D}$. (see Figure 2) to bring the salinity back below 40,000 $\mathrm{mg} / 1$. Actually, this is too optimistic. A program of installing 200 MW each year, beginning in, say, 1982 may be more in tune with reality. In this case, reachieving $40,000 \mathrm{mg} / 1$ will require until about 2030 A.D. An additional consequence of this method is that the level of the Sea would be reduced about four feet. Technically, it is not yet established whether Salton Sea water can be used successfully for injection purposes. The behavior of the organic materials and nutrients in the water may cause operating difficulties, and even the behavior of the inorganic salts may bring about blockage in the equipment or the reservoirs. 


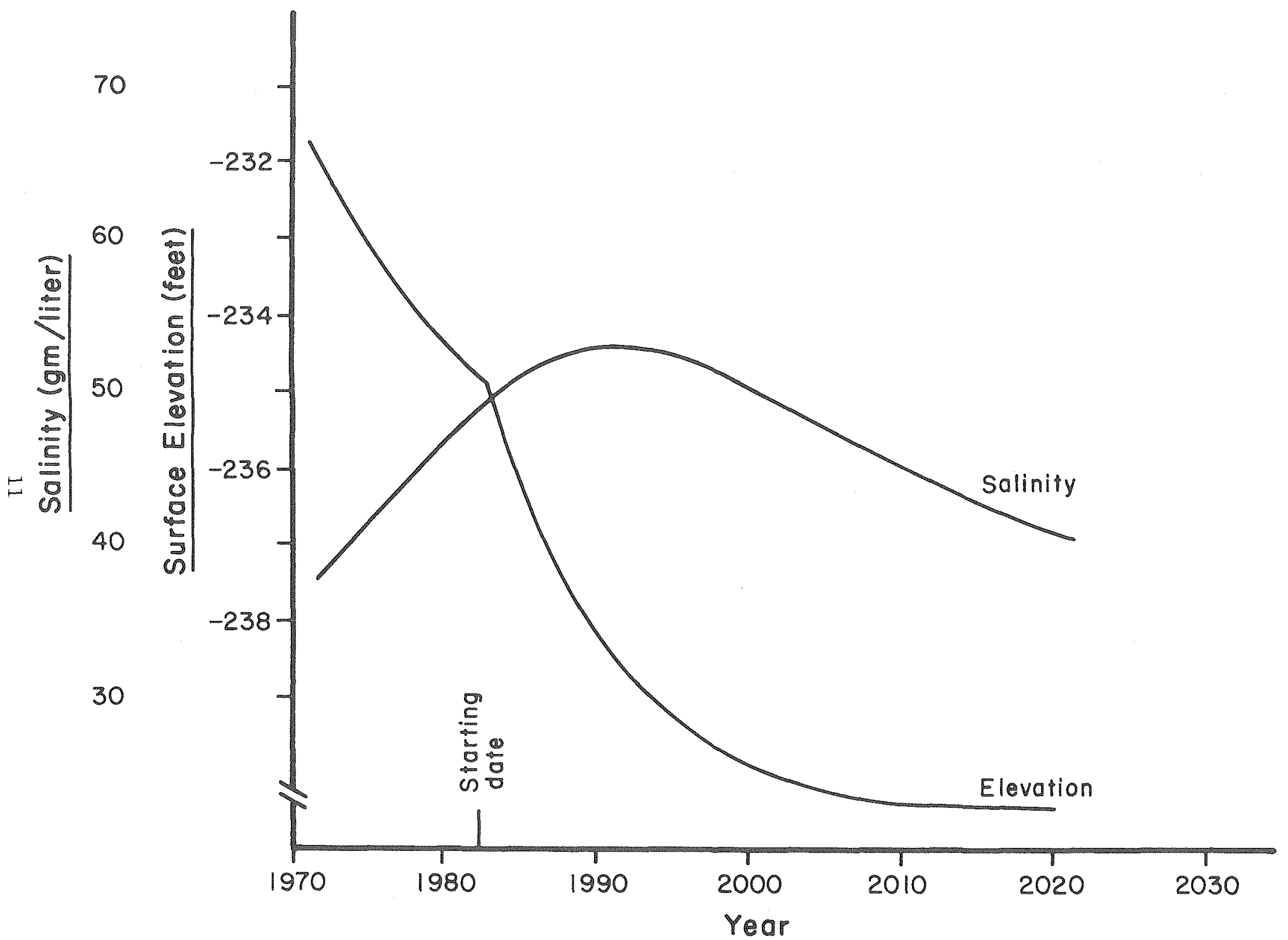

Figure 2 Behavior of Salton Sea $(120,000$ acre-feet/year pumped out $)$ 
A sinilar requirement for injection water replenishment might come about if geothermal brine is used for feedstock in water distillation processes, or for combinations of electrical, chemical, and fresh water production. An endless variety of combinations could be used as examples, but the key number, as far as the Salton Sea is concerned, is the total annual withdrawal. It has been suggested that Salton Sea water might be employed in evaporative cooling towers, as would be used in electrical or water production plants. This is indeed a possibility, but would impose very severe conditions on the towers. Only a limited salt concentration increase would be practical, thus the blowdown flow from the towers would be large, possibly as large as the evaporative 1oss. Owing to the very salty nature of the fluid, drift losses would need to be very carefully controlled. If these practical problems could be overcome, several useful plant operations can be conceived. Consider, for example, an electric generating plant complex of 1,000 MW capacity. If it is planned to save the condensate as desalted water (about 60,000 acre-feet/year), an equivalent amount of evaporative cooling water must be provided. Also, an equivalent amount of water could be used as injection fluid, to accompany the waste brine that was separated from the steam and then reinjected. Thus about 120,000 acre-feet of make-up water could be used by the generating complex. The effect of withdrawIng 120,000 acre-feet/year from the Salton Sea has been shown.

Summary

The effects of geothermal development on the Salton Sea can range from near-catastrophic through neutral to beneficial. Possibly the most damaging would be the direct flow of geothermal brines into the Sea in large quantity (e.g., flow from several typical production wells). Not only would the rate of salinity increase be noticeably accelerated, but the added water would aggravate an already disturbingly high surface level situation. Both water quantity and quality considerations suggest 
that the Salton Sea cannot be used as a repository for large amounts of geothermal brine. Regional Water Quality Control Board regulations already preclude this possibilicy.

Diversion of some of the inflow to the Salton Sea will have the beneficial effect of lowering the surface level, but will also tend to increase the salinity level. For the cooling water diversion to a 100 MW electric power plant, both effects are fairly small. For a 1,000 MW plant, the effects are substantial. Whether to permit such diversions is an important policy decision.

The use of Salton Sea water for injection fluid to maintain geothermal reservoir pressure will lower the elevation of the Sea and reduce its salinity. However, these beneficial effects will only be felt after the passage of many years, thus geothermal development does not offer an instant solution to the immediate problems of water quality in the Salton Sea. 


\section{SUMARY OF ACTIONS AND CONSEQUENCES}

\begin{tabular}{|c|c|c|c|}
\hline \multirow{2}{*}{ Possible Action } & \multicolumn{3}{|c|}{ Results on Salton Sea } \\
\hline & Size of P1ants & Water Level & Salinity \\
\hline \multirow[t]{4}{*}{ Direct discharge of brine } & One well & negligible & negligible \\
\hline & $\begin{array}{l}100 \text { MW (Salton } \\
\text { Sea KGRA) }\end{array}$ & $0.4 \mathrm{ft}$ rise & $\begin{array}{l}\text { doubles rate of } \\
\text { increase }\end{array}$ \\
\hline & $\begin{array}{l}100 \mathrm{MW} \text { (other } \\
\text { location) }\end{array}$ & 0.4 ft rise & $\begin{array}{l}20 \% \text { higher rate } \\
\text { of increase }\end{array}$ \\
\hline & $1000 \mathrm{MW}$ & over $10 \mathrm{ft}$ rise & \\
\hline Reservoir injection of Sea water & $2000 \mathrm{MW}$ & $4 \mathrm{ft}$ fall & $\begin{array}{l}\text { Safely stabilized } \\
\text { in } 40 \text { years }\end{array}$ \\
\hline
\end{tabular}




\section{$\underline{\text { References }}$}

1. Pomeroy, Richard D. and Cruse, Henry, "A Reconnaissance Study and Preliminary Report on a Water Quality Control Plant for Salton Sea," Pomeroy, Johnson, and Bailey for California State Water Quality Board, December 1965.

2. Salton Sea Project - California, "Federal-State Reconnaissance Report," U.S. Department of Interior and the Resources Agency of California, October 1969.

3. Goldsmith, M., "Salinity Control Study, Salton Sea Project," the Aerospace Corp. Report No. ATR-71(S9990)-5, February 1971.

4. Salton Sea Project - California, "Federal-State Feasibility Report," U.S. Department of Interior and the Resources Agency of California, April 1974.

5. Goldsmith, Martin, "Salton Sea, California's Little Orphan Ocean," The Western Tanager, vo1.40, nos. 1 and 2, September, October 1973, Los Angeles Audubon Society.

6. Swajiar, Arthur, "Statement before the Geothermal Resources Board, October 22, 1970," Compendium of Papers, Imperial Valley - Salton Sea Area Geothermal Hearing, the Resources Agency of California, October 1970 .

7. Rex, Robert $W_{0}$ " "Phase I - The Imperial Valley Project," Institute of Geophysics and Planetary Physics, University of California, Riverside, October 1968.

8. Geothermal Resource Investigations, "Developmental Concepts," U.S. Bureau of Reclamation, January 1972.

9. Eaton, Andrew, "Trace Element Problems, Geothermal Research Study in the Salton Sea Region of California," Environmental Quality Laboratory Open File Report, California Institute of Technology, July 1975.

10. Goldsmith, Martin, "Geothermal Resources in California - Potentials and Problems," Environmental Quality Laboratory Report No. 5, California Institute of Technology, December 1971.

11. Goldsmith, Martin, "Siting Nuclear Power Plants in California - The Near-Term Alternatives," Environmental Quality Laboratory Report No. 8, California Institute of Technology, July 1973.

12. Electric Power Generation using Geothermal Brine Resources for a Proof-of-Concept Facility, Bechtel Corp., May 1975. 